\title{
TNFRSF14 wt Allele
}

National Cancer Institute

\section{Source}

National Cancer Institute. TNFRSF14 wt Allele. NCI Thesaurus. Code C97844.

Human TNFRSF14 wild-type allele is located in the vicinity of $1 \mathrm{p} 36.32$ and is approximately $10 \mathrm{~kb}$ in length. This allele, which encodes tumor necrosis factor receptor superfamily member 14 protein, is involved in both ligand binding and signal transduction. 